\title{
ISOLASI PROTEIN SELAMA PROSES PENGAMBILAN KITIN DARI KULIT UDANG
}

\author{
Kherliyanda Febriani, Fitri Hariani Nurza, Iriany \\ Departemen Teknik Kimia, Fakultas Teknik, Universitas Sumatera Utara, \\ Jl. Almamater Kampus USU, Medan 20155, Indonesia \\ Email : kherliyandafebriani@yahoo.com
}

\begin{abstract}
Abstrak
Udang merupakan salah satu komoditas perikanan Indonesia yang bernilai ekonomis tinggi. Produksi kulit udang ini biasanya berkisar 40-45\% dari udang mentah. Kulit udang ini tersusun atas protein, kitin, mineral dan karoten, sehingga sangat potensial digunakan sebagai bahan baku isolasi protein. Penelitian ini bertujuan untuk mengetahui faktor-faktor yang berpengaruh dalam pengambilan kembali protein serta mengoptimasi kondisi proses deproteinasi untuk menghasilkan jumlah protein yang maksimal. Rancangan percobaan ini menggunakan response surface methodology melalui 2 tahapan proses yaitu deproteinasi dan ekstraksi protein menggunakan kulit udang dan pelarut $\mathrm{KOH}$ dengan rasio 1:10 (w/v) pada konsentrasi 1,3 M; $2 \mathrm{M} ; 3 \mathrm{M} ; 4 \mathrm{M} ; 4,7 \mathrm{M}$, suhu reaksi $37^{\circ} \mathrm{C} ; 40{ }^{\circ} \mathrm{C} ; 45^{\circ} \mathrm{C} ; 50{ }^{\circ} \mathrm{C} ; 53{ }^{\circ} \mathrm{C}$ dan waktu reaksi 40 menit; 60 menit; 90 menit; 120 menit; 140 menit. Suhu reaksi merupakan faktor yang sangat mempengaruhi dalam proses pengambilan kembali protein. Diperoleh yield protein maksimum sebesar

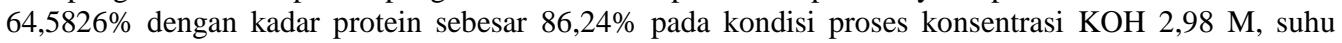
reaksi $45,76{ }^{\circ} \mathrm{C}$ dan waktu reaksi 90,51 menit. Potensi ekonomi dari pengambilan kembali protein selama proses isolasi kitin dari kulit udang sangat menguntungkan.
\end{abstract}

Kata kunci: kulit udang, response surface methodology, deproteinasi, protein, ekstraksi

\begin{abstract}
Shrimp is one of the Indonesia fishery commodities with high economic value. The production of shrimp shells is usually 40-45\% from crude shrimp. Shrimp shell contain protein, chitin, minerals and carotenoids. It is very potential to be used as materials for isolation of protein. This experiment is to determine factors that effect protein recovery and optimize deproteination process conditions to produce high yield of protein. The design of experiment used response surface methodology. It is 2 steps consist of deproteination and protein extraction process using shrimp shells and $\mathrm{KOH}$ solution in comparison 1:10 $(w / v)$. The concentration of $\mathrm{KOH}$ are $1,3 \mathrm{M} ; 2 \mathrm{M} ; 3 \mathrm{M} ; 4 \mathrm{M} ; 4,7 \mathrm{M}$. The reaction temperatures are $37^{\circ} \mathrm{C}$; $40{ }^{\circ} \mathrm{C} ; 45^{\circ} \mathrm{C} ; 50^{\circ} \mathrm{C} ; 53{ }^{\circ} \mathrm{C}$ and the reaction times are 40 minutes, 60 minutes, 90 minutes, 120 minutes, 140 minutes. Reaction temperature is the main factor influence protein recovery process. The highest protein yield obtained is $64,5826 \%$ with protein content is $86,24 \%$ using $\mathrm{KOH}$ solution 2,98 M, reaction temperature $45,76^{\circ} \mathrm{C}$ and reaction time 90,51 minute. Economic potential by protein recovery during isolation of chitin from shrimp shells is profitable.
\end{abstract}

Keywords: shrimp shell, response surface methodology, deproteination, protein, extraction

\section{Pendahuluan}

Total produksi penangkapan dan perikanan udang dunia menurut Food and Agriculture Organization pada tahun 2009 berkisar 6 juta ton pada tahun 2006 dan mempunyai nilai dagang yang cukup tinggi dengan persentase $16 \%$ dari total perdagangan produk perikanan dunia $[10,17]$. Udang juga merupakan salah satu komoditas sektor perikanan Indonesia yang bernilai ekonomis tinggi dengan pangsa pasar di manca negara cukup luas dan cenderung meningkat, sehingga pada era 1980-an udang pernah menjadi penyumbang devisa negara keempat dari sektor non migas setelah kayu, tekstil dan karet [16].

Menurut Kementerian Kelautan dan Perikanan pada tahun 2014, bahwa perkembangan produksi udang nasional tahun 2010-2014 mengalami kenaikan rata-rata sebesar 14,03\% dengan rincian kenaikan rata-rata udang windu $4,08 \%$ dan udang vaname $20,49 \%$ [6]. Kemudian, pemerintah telah menargetkan produksi udang sebesar 786.000 ton pada tahun 2015 dengan rincian udang windu 189.700 ton, udang vaname 518.600 ton dan jenis udang lain sebesar 77.600 ton [12].

Data realisasi nilai ekspor produk perikanan oleh Kementerian Kelautan dan Perikanan pada tahun 2014 mencapai USD 4,64 miliar. Berdasarkan data ekspor tersebut, komoditas yang memberikan kontribusi nilai tertinggi adalah udang, yakni sebesar $45,4 \%$ atau setara dengan USD 2,11 miliar. Volume ekspor udang tersebut mencapai 191.139 ton atau meningkat dari pencapaian tahun 2013 sebesar 165.000 ton [6]. Jumlah limbah ekspor ini sangatlah besar, karena normalnya udang dijual tanpa kepala dan kulit. 
Produksi kulit udang oleh industri pengolahan udang ini biasanya berkisar $40-45 \%$ dari udang mentah, itu berarti akan tersedia kulit udang sebanyak 76.455 ton apabila kita bandingkan dengan volume ekspor pada tahun 2014. Kulit tersebut akan dibuang begitu saja ke lingkungan sehingga akan menyebabkan polusi yang berbahaya bagi lingkungan [13].

Kandungan yang terdapat dalam kulit udang tersusun atas protein $(35-40 \%)$, kitin (10-15\%), mineral (10-15\%) dan karoten, sehingga kulit udang sangat berpotensi sebagai sumber protein yang baik. Protein tersebut bisa digunakan sebagai suplemen dalam makanan hewan dan juga suplemen diet bernilai tinggi bagi manusia [1,4].

Tujuan utama penelitian ini adalah untuk mengkaji faktor-faktor yang berpengaruh dalam pengambilan kembali protein dan kadar prorein yang diperoleh dari kulit udang. Selain itu untuk mengoptimasi kondisi proses deproteinasi untuk menghasilkan jumlah protein yang maksimal.

\section{Metodologi Penelitian}

\section{Alat dan Bahan}

Bahan baku yang digunakan adalah kulit udang dan larutan $\mathrm{KOH}$ dengan perbandingan 1:10 (w/v), sebagai bahan pembantu digunakan $\mathrm{HCl} 1 \mathrm{~N}$ dan air. Rangkaian alat utama yang digunakan ialah alat proses deproteinasi, filtrasi dan sentrifuge. Rangkaian peralatan yang digunakan dapat dilihat pada Gambar 1.

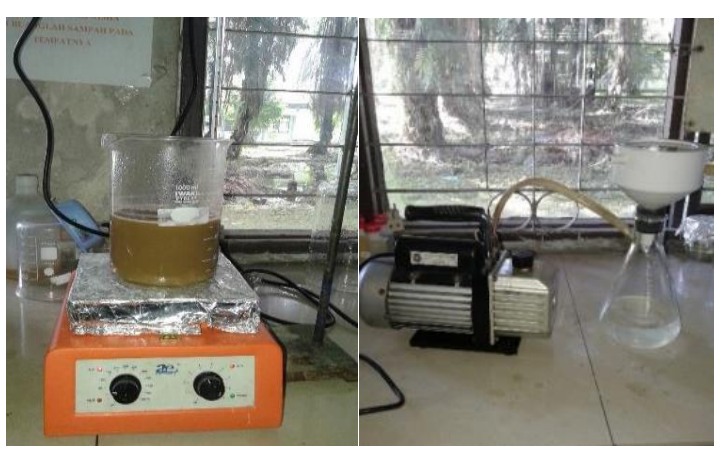

(a) (b)

Gambar 1. (a) Deproteinasi (b) Filtrasi

\section{Rancangan Percobaan}

Penelitian dilakukan dengan memvariasikan konsentrasi $\mathrm{KOH}$, temperatur dan waktu reaksi. Rasio bahan baku dan KOH yang digunakan 1:10 (w/v) dengan ukuran partikel sampel 50 mesh. Massa kering bahan baku, yaitu 100 gram. Dengan memasukkan nilai masing-masing variabel di atas (nilai terendah dan tertinggi) seperti Tabel 1 pada Minitab 16 Statistical Software (trial version), diperoleh central composite design dengan total run sebanyak 20 , seperti yang terlihat pada Tabel 2 .
Tabel 1. Kode Level dan Nilai Level Variabel Berubah

\begin{tabular}{|c|c|c|c|c|c|}
\hline Variabel Berubah & $(-\alpha)$ & $(-1)$ & $(0)$ & $(+1)$ & $(+\alpha)$ \\
\hline$X_{1}$ & 1,3 & 2 & 3 & 4 & 4,7 \\
\hline$X_{2}$ & 37 & 40 & 45 & 50 & 53 \\
\hline$X_{3}$ & 40 & 60 & 90 & 120 & 140 \\
\hline
\end{tabular}

\section{Prosedur Percobaan}

Serbuk kulit udang (disimbolkan dengan huruf K) sebanyak 100 gram ditambahkan larutan $\mathrm{KOH}$ (disimbolkan dengan huruf $\mathrm{C}$ ). Campuran serbuk kulit udang dan $\mathrm{KOH}$ dipanaskan sambil diaduk. Larutan didinginkan kemudian disaring dan dinetralkan dengan aquadest sehingga diperoleh padatan dan filtrat. Filtrat yang diperoleh dicuci dengan air lalu ditambahkan larutan $\mathrm{HCl} 1 \mathrm{~N}$ agar $\mathrm{pH}$-nya menjadi 4,5 yang merupakan $\mathrm{pH}$ isoelektrik protein. Kemudian campuran tersebut disentrifugasi lalu didekantasi sehingga diperoleh endapan protein. Endapan yang diperoleh disaring menggunakan kertas saring Whatmann No.1. Endapan tersebut dicuci hingga $\mathrm{pH}$ kembali netral. Kemudian, dikeringkan menggunakan oven pada suhu $40{ }^{\circ} \mathrm{C}$. Hasil yang diperoleh dilakukan analisis kadar air, kadar abu, kadar protein dan kadar $\mathrm{pH}$.

Tabel 2. Central Composite Design Untuk Isolasi Protein dari Kulit Udang

\begin{tabular}{|c|c|c|c|c|c|}
\hline Run & $\begin{array}{l}\mathrm{K}: \mathrm{C} \\
(\mathrm{w} / \mathrm{v})\end{array}$ & $\begin{array}{c}\text { Nomor } \\
\text { Mesh }\end{array}$ & $\begin{array}{c}\text { Konsentrasi } \\
\mathrm{KOH}(\mathrm{M})\end{array}$ & $\begin{array}{l}\text { Suhu } \\
\left({ }^{\circ} \mathrm{C}\right)\end{array}$ & $\begin{array}{l}\text { Waktu } \\
\text { (menit) }\end{array}$ \\
\hline 1 & \multirow{20}{*}{$1: 10$} & \multirow{20}{*}{50} & 2 & 40 & 60 \\
\hline 2 & & & 4 & 40 & 60 \\
\hline 3 & & & 2 & 50 & 60 \\
\hline 4 & & & 4 & 50 & 60 \\
\hline 5 & & & 2 & 40 & 120 \\
\hline 6 & & & 4 & 40 & 120 \\
\hline 7 & & & 2 & 50 & 120 \\
\hline 8 & & & 4 & 50 & 120 \\
\hline 9 & & & 1,3 & 45 & 90 \\
\hline 10 & & & 4,7 & 45 & 90 \\
\hline 11 & & & 3 & 37 & 90 \\
\hline 12 & & & 3 & 53 & 90 \\
\hline 13 & & & 3 & 45 & 40 \\
\hline 14 & & & 3 & 45 & 140 \\
\hline 15 & & & 3 & 45 & 90 \\
\hline 16 & & & 3 & 45 & 90 \\
\hline 17 & & & 3 & 45 & 90 \\
\hline 18 & & & 3 & 45 & 90 \\
\hline 19 & & & 3 & 45 & 90 \\
\hline 20 & & & 3 & 45 & 90 \\
\hline
\end{tabular}

\section{Hasil}

\section{Karakteristik Bahan Baku}

Analisis terhadap bahan baku serbuk kulit udang berukuran 50 mesh, meliputi analisis kadar air, kadar abu dan kadar protein. Hasil analisis bahan baku tersebut ditunjukkan pada tabel 3 . 
Tabel 3. Hasil Analisis Karakteristik Bahan Baku Kulit Udang

\begin{tabular}{|l|c|}
\hline \multicolumn{1}{|c|}{ Parameter } & Hasil Analisis \\
\hline Kadar air & $2,25 \%$ \\
\hline Kadar abu & $3,78 \%$ \\
\hline Kadar Protein & $30,20 \%$ \\
\hline Kadar $\mathrm{pH}$ & 7 \\
\hline
\end{tabular}

Kadar air pada bahan baku cukup rendah, yaitu sebesar 2,25\%. Kadar air yang tinggi mengakibatkan mudahnya bakteri, kapang dan khamir untuk berkembang biak, sehingga akan terjadi perubahan pada bahan [11]. Selain itu kadar abu bahan baku juga cukup rendah, yaitu sebesar 3,78\% dimana kadar abu yang tinggi mempengaruhi kelarutan bahan [14]. Kemudian juga dilakukan analisis kadar protein untuk mengetahui kadar protein bahan baku yang digunakan dan hasil analisisnya menunjukkan bahwa kadar protein pada bahan baku juga cukup tinggi, yaitu sebesar 30,20\% sehingga bahan baku ini cukup potensial digunakan sebagai sumber protein. Adapun untuk kadar $\mathrm{pH}$ bahan baku dari kulit udang yang digunakan adalah 7 yang berarti kulit udang tersebut berada pada $\mathrm{pH}$ netral.

\section{Analisis Pengaruh Variabel}

Tabel 4 menunjukkan rancangan percobaan yang telah dilakukan sesuai dengan desain tabel pengkodean percobaan.

Tabel 4. Yield Protein dengan Central Composite Design

\begin{tabular}{|c|c|c|c|c|}
\hline Run & $\begin{array}{c}\text { Konsentrasi } \\
\text { KOH }\left(\mathbf{X}_{\mathbf{1}}\right)\end{array}$ & $\begin{array}{c}\text { Suhu } \\
\left(\mathbf{X}_{\mathbf{2}}\right)\end{array}$ & $\begin{array}{c}\text { Waktu } \\
\left(\mathbf{X}_{\mathbf{3}}\right)\end{array}$ & $\begin{array}{c}\% \text { Yield } \\
(\mathbf{Y})\end{array}$ \\
\hline 1 & 2 & 40 & 60 & 34,24 \\
\hline 2 & 4 & 40 & 60 & 34,77 \\
\hline 3 & 2 & 50 & 60 & 55,56 \\
\hline 4 & 4 & 50 & 60 & 29,27 \\
\hline 5 & 2 & 40 & 120 & 33,44 \\
\hline 6 & 4 & 40 & 120 & 32,25 \\
\hline 7 & 2 & 50 & 120 & 32,72 \\
\hline 8 & 4 & 50 & 120 & 57,69 \\
\hline 9 & 1,3 & 45 & 90 & 46,02 \\
\hline 10 & 4,7 & 45 & 90 & 42,91 \\
\hline 11 & 3 & 37 & 90 & 46,75 \\
\hline 12 & 3 & 53 & 90 & 40,13 \\
\hline 13 & 3 & 45 & 40 & 35,43 \\
\hline 14 & 3 & 45 & 140 & 37,42 \\
\hline 15 & 3 & 45 & 90 & 64,44 \\
\hline 16 & 3 & 45 & 90 & 64,42 \\
\hline 17 & 3 & 45 & 90 & 64,40 \\
\hline 18 & 3 & 45 & 90 & 64,41 \\
\hline 19 & 3 & 45 & 90 & 64,40 \\
\hline 20 & 3 & 45 & 90 & 64,39 \\
\hline
\end{tabular}

Tabel 5 menunjukkan pengaruh linier, kuadratik dan interaksi antara faktor-faktor yang diamati terhadap parameter respon. Adapun suku yang terdiri dari satu faktor $\left(X_{n}\right)$ menunjukkan efek linier sedangkan suku yang terdiri dari dua faktor $\left(\mathrm{X}_{\mathrm{n}} \mathrm{X}_{\mathrm{n}}\right)$ menunjukkan efek interaksi antara ke dua faktor (variabel). Suku yang berpangkat dua $\left(\mathrm{X}_{\mathrm{n}}{ }^{2}\right)$ menunjukkan efek kuadratik terhadap hasil. Nilai $\mathrm{P}$ dan $\mathrm{T}$ digunakan untuk mengetahui signifikan atau tidaknya masing-masing suku dan interaksi antara faktor, dengan nilai $\mathrm{P}$ yang diinginkan $<0,05$. Semakin kecil nilai $P$, semakin signifikan harga koefesiennya dan semakin berperan terhadap hasil yang diperoleh. Sedangkan nilai $\mathrm{T}$ menunjukkan perbedaan ratarata yang signifikan antara satu variabel dengan variabel-variabel lainnya. Semakin besar nilai $\mathrm{T}$ maka semakin signifikan harga koefisiennya dan semakin berperan terhadap hasil penelitian.

Tabel 5. Koefisien Regresi

\begin{tabular}{|l|r|r|r|}
\hline $\begin{array}{c}\text { Model } \\
\text { Parameter }\end{array}$ & \multicolumn{1}{c|}{ Koefisien } & T-value & $\boldsymbol{P}$-value \\
\hline Intercept & $-651,399$ & 21,869 & $0,000^{*}$ \\
\hline $\mathrm{X}_{1}$ & 25,6025 & 0,270 & 0,793 \\
\hline $\mathrm{X}_{2}$ & 27,4965 & 1,101 & 0,297 \\
\hline $\mathrm{X}_{3}$ & 1,09471 & 0,210 & 0,838 \\
\hline $\mathrm{X}_{1}{ }^{2}$ & $-7,32757$ & $-3,849$ & $0,003^{*}$ \\
\hline $\mathrm{X}_{2}{ }^{2}$ & $-0,307599$ & $-4,040$ & $0,002^{*}$ \\
\hline $\mathrm{X}_{3}{ }^{2}$ & $-0,0113002$ & $-5,343$ & $0,000^{*}$ \\
\hline $\mathrm{X}_{1} \mathrm{X}_{2}$ & $-0,0165000$ & $-0,032$ & 0,975 \\
\hline $\mathrm{X}_{1} \mathrm{X}_{3}$ & 0,206417 & 2,424 & $0,036^{*}$ \\
\hline $\mathrm{X}_{2} \mathrm{X}_{3}$ & 0,00741667 & 0,435 & 0,672 \\
\hline
\end{tabular}

*signifikansi pada nilai $p \leq 0,05$

Hasil komputasi dengan menggunakan perangkat lunak Minitab dapat dilihat pada persamaan (1) yang menggambarkan hubungan antara yield protein dengan faktor konsentrasi $\mathrm{KOH}$, suhu dan waktu reaksi dengan $\mathrm{R}^{2}$ (koefisien korelasi) $=85,20 \%$.

$$
\begin{aligned}
\mathrm{Y}_{\text {yield }}= & -651,399+25,6025 \mathrm{X}_{1}+27,4965 \mathrm{X}_{2}+ \\
& 1,09471 \mathrm{X}_{3}-7,32757 \mathrm{X}_{1}{ }^{2}-0,307599 \mathrm{X}_{2}^{2} \\
& -0,0113002 \mathrm{X}_{3}^{2}-0,0165000 \mathrm{X}_{1} \mathrm{X}_{2}+ \\
& 0,206417 \mathrm{X}_{1} \mathrm{X}_{3}+0,00741667 \mathrm{X}_{2} \mathrm{X}_{3} \ldots . .(1)
\end{aligned}
$$

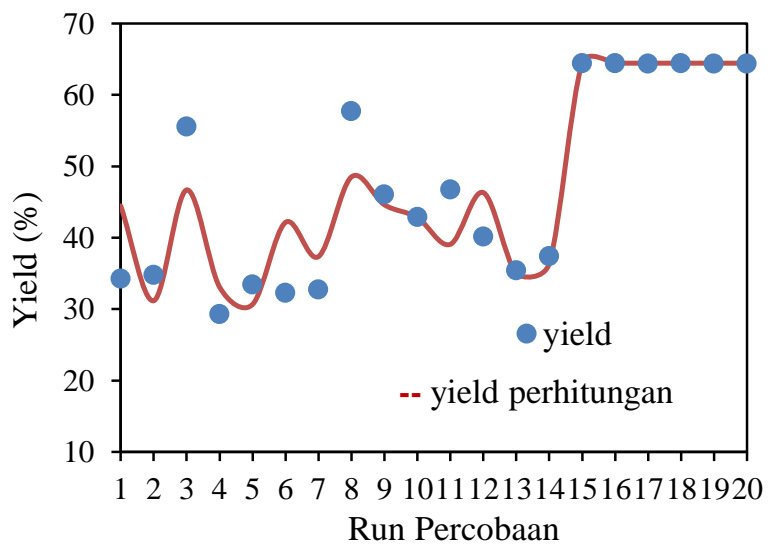

Gambar 2. Perbandingan Yield Protein Hasil Percobaan dengan Yield Prediksi Model 
Gambar 2 menunjukkan perbandingan yield protein yang dihasilkan dari percobaan dengan yield prediksi yang diperoleh menggunakan persamaan model (1) dengan titik optimum untuk kondisi recovery protein selama proses isolasi kitin dari kulit udang, yaitu konsentrasi $\mathrm{KOH} 2,98 \mathrm{M}$, suhu reaksi $45,76^{\circ} \mathrm{C}$ dan waktu reaksi 90,51 menit. Uji validasi persamaan model (1) dilakukan pada titik optimum, dimana yield yang diperoleh pada titik optimum adalah $64,5826 \%$ sedangkan hasil perhitungan model sebesar 64,6139\%. Dengan demikian, diperoleh persen error rata-rata sebesar $0,0484 \%$.

\section{Pengaruh Variabel Konsentrasi KOH dan Waktu Reaksi terhadap Yield Protein}

Gambar 3 menampilkan hubungan antara konsentrasi $\mathrm{KOH}$ dan waktu reaksi terhadap yield protein yang diperoleh.

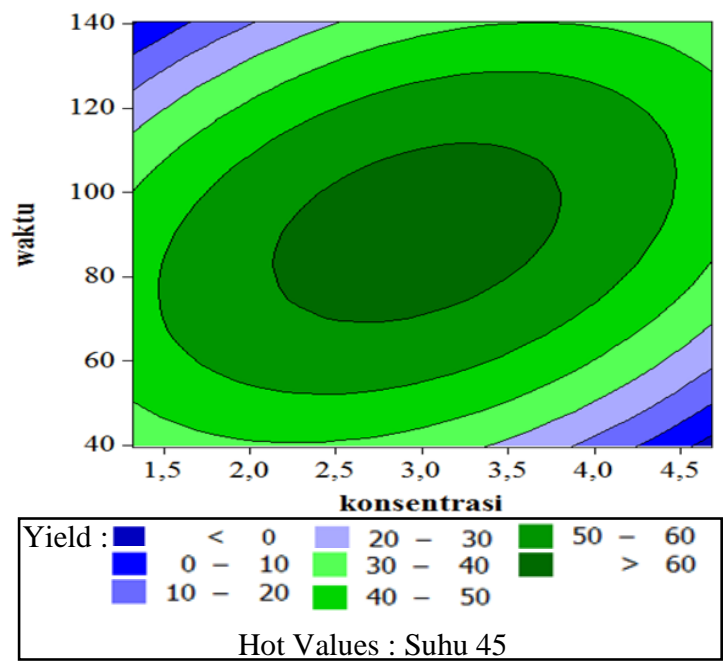

Gambar 3. Interaksi antara Konsentrasi KOH dan Waktu Reaksi dengan Yield Protein

Zona kondisi operasi optimum berdasarkan gambar 3 di atas, yaitu pada penggunaan konsentrasi $\mathrm{KOH} \mathrm{2,25} \mathrm{M} \mathrm{-} \mathrm{3,75} \mathrm{M} \mathrm{dengan} \mathrm{waktu}$ reaksi antara 70 menit - 110 menit akan menghasilkan yield protein $60 \%$ - $70 \%$. Berdasarkan grafik tersebut maka pada temperatur yang tetap, peningkatan konsentrasi $\mathrm{KOH}$ dan waktu reaksi akan meningkatkan persen yield protein yang dihasilkan sampai mencapai kondisi operasi optimum, kemudian yield menurun.

Pengambilan kembali protein (protein recovery) dari kulit udang yang telah dilakukan oleh Benhabiles, dkk., menjelaskan bahwa derajat pengambilan kembali protein yang dihasilkan ditentukan oleh beberapa hal, yaitu konsentrasi, suhu, lama proses dan perbandingan rasio padatan dengan pelarut. Berdasarkan penelitian tersebut maka penggunaan $\mathrm{KOH}$ pada konsentrasi dan waktu yang optimum menghasilkan yield protein yang lebih baik $[10,15]$.

Kemudian dengan bertambahnya waktu reaksi, maka kontak antara solute dan solvent semakin lama semakin meningkat, sehingga banyak solute yang terambil, hal ini menyebabkan kadar protein meningkat [7].

\section{Pengaruh Variabel Konsentrasi KOH dan Temperatur terhadap Yield Protein}

Gambar 4 menunjukkan hubungan antara konsentrasi $\mathrm{KOH}$ dan temperatur reaksi terhadap yield protein yang diperoleh.

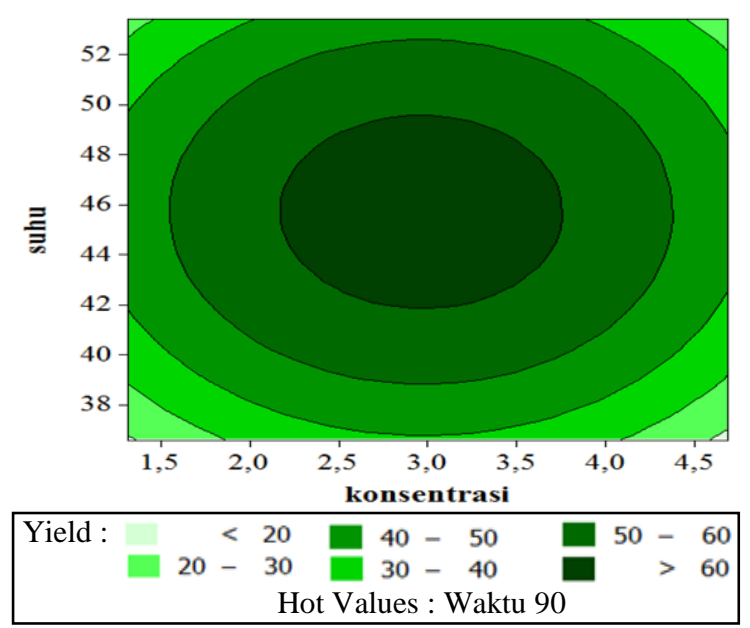

Gambar 4. Interaksi antara Konsentrasi KOH dan Temperatur Reaksi dengan Yield Protein

Zona kondisi operasi optimum berdasarkan gambar 4 di atas, yaitu pada penggunaan konsentrasi $\mathrm{KOH} 2,25 \mathrm{M}-3,75 \mathrm{M}$ dengan suhu reaksi $43{ }^{\circ} \mathrm{C}-49{ }^{\circ} \mathrm{C}$ akan menghasilkan persen yield protein $60 \%-70 \%$. Berdasarkan grafik di atas maka pada waktu yang tetap, peningkatan konsentrasi $\mathrm{KOH}$ dan suhu reaksi akan meningkatkan persen yield protein yang dihasilkan sampai mencapai kondisi operasi optimum, kemudian yield menurun.

Dari hasil analisis yang diperoleh bahwa variabel suhu reaksi memiliki pengaruh dengan nilai positif yang lebih besar dibandingkan variabel lainnya, yaitu 27,4965. Hal ini sesuai dengan sifat fisik protein bahwa protein akan mengalami denaturasi atau perubahan struktur sekunder, tersier dan kuartener karena panas biasanya terjadi pada suhu $50{ }^{\circ} \mathrm{C}-80{ }^{\circ} \mathrm{C}$ [5]. Pengambilan kembali protein (protein recovery) dari kulit udang yang telah dilakukan oleh Benhabiles, dkk., ,menunjukkan bahwa pada proses deproteinasi dengan penggunaan $\mathrm{KOH}$ pada konsentrasi dan waktu yang optimum menghasilkan yield protein yang lebih baik $[3,10]$. Sehingga protein yang diperoleh akan lebih tinggi menggunakan $\mathrm{KOH}$. 
Berdasarkan penelitian yang telah dilakukan, yield terus meningkat hingga konsentrasi $4 \mathrm{M}$ dan temperatur reaksi $50{ }^{\circ} \mathrm{C}$ kemudian akan menurun pada temperatur reaksi di atas $50{ }^{\circ} \mathrm{C}$, hal ini dapat dikarenakan rantai polimer protein akan rusak pada temperatur yang lebih tinggi sehingga menyebabkan penurunan protein [9]. Kelarutan protein juga efektif pada suhu di bawah $60{ }^{\circ} \mathrm{C}$ karena suhu reaksi di atas $60{ }^{\circ} \mathrm{C}$ akan menyebabkan ikatan struktur protein mengalami denaturasi sehingga protein yang tertinggal di dalam serbuk kulit udang akan semakin banyak dan kelarutan protein dalam larutan akan menurun [7]. Sehingga, filtrat yang diperoleh setelah deproteinasi memiliki kandungan protein yang rendah.

\section{Pengaruh Variabel Waktu Reaksi dan Temperatur terhadap Yield Protein}

Gambar 5 menampilkan hubungan antara waktu dan temperatur reaksi terhadap yield protein yang diperoleh.

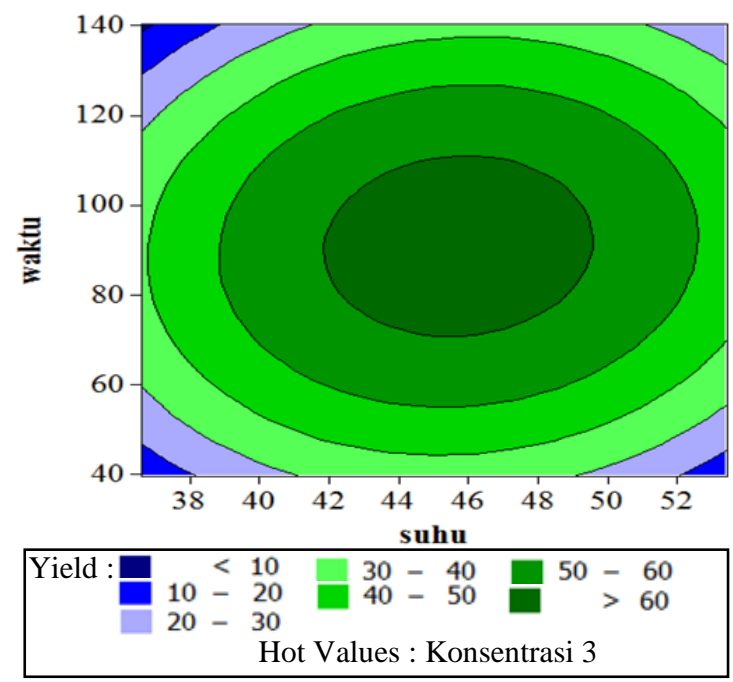

Gambar 5. Interaksi antara Waktu Reaksi dan Suhu Reaksi dengan Yield Protein : (a) Permukaan Respon ; (b) Plot Kontur

Zona kondisi operasi optimum berdasarkan gambar 5 di atas, yaitu pada waktu 70 menit 110 menit dengan temperatur reaksi $43{ }^{\circ} \mathrm{C}-50{ }^{\circ} \mathrm{C}$ akan menghasilkan persen yield protein $60 \%$ $70 \%$. Sehingga pada waktu yang tetap, peningkatan waktu reaksi dan suhu reaksi akan meningkatkan persen yield protein yang dihasilkan sampai mencapai kondisi operasi optimum, kemudian yield menurun.

Dari hasil analisis yang telah dilakukan bahwa suhu merupakan variabel yang sangat berpengaruh seperti yang telah dijelaskan sebelumnya. Selain suhu dapat dilihat bahwa waktu juga mempunyai pengaruh signifikan yang cukup besar terhadap persen yield yang dihasilkan. Semakin meningkatnya waktu reaksi, maka akan semakin meningkatkan kelarutan protein dan semakin banyak protein yang terambil. Hubungan waktu reaksi terhadap hasil protein yang diperoleh dibandingkan dengan hasil penelitian lainnya sudah dijelaskan sebelumnya begitu pula dengan hubungan suhu reaksi. Berdasarkan penelitian tersebut juga diperoleh hasil yang sama bahwa yield akan terus meningkat seiring bertambahnya waktu dan juga suhu reaksi, kemudian menurun. Selain itu waktu reaksi yang lebih lama akan menghasilkan protein dengan viskositas dan berat molekul yang rendah [15].

\section{Karakteristik Protein}

Protein yang diperoleh dapat digunakan sebagai bahan pakan yang cukup baik. Adapun perbandingan parameter standar mutu protein sebagai bahan pakan dengan hasil penelitian ditunjukkan pada tabel 6 .

Tabel 6. Perbandingan Standar Mutu Protein sebagai Bahan Pakan dengan Hasil Penelitian

\begin{tabular}{|l|c|c|}
\hline Parameter & $\begin{array}{c}\text { Standar } \\
\text { Mutu Protein }\end{array}$ & $\begin{array}{c}\text { Hasil } \\
\text { Penelitian }\end{array}$ \\
\hline Kadar air & $10 \%$ & $1,31 \%$ \\
\hline Kadar abu & $40 \%$ & $86,24 \%$ \\
\hline Kadar protein & $9 \%$ & $1,96 \%$ \\
\hline Kadar pH & 7 & 7 \\
\hline
\end{tabular}

Pada tabel 6 terlihat bahwa kadar air protein yang diperoleh telah memenuhi standar mutu protein sebagai pakan, dimana kadar air yang diperoleh sebesar 1,31\% kurang dari $10 \%$. Kadar abu yang diperoleh sebesar $1,96 \%$ yang telah memenuhi standar mutu kadar abu protein sebagai bahan pakan, yaitu maksimal $9 \%$.

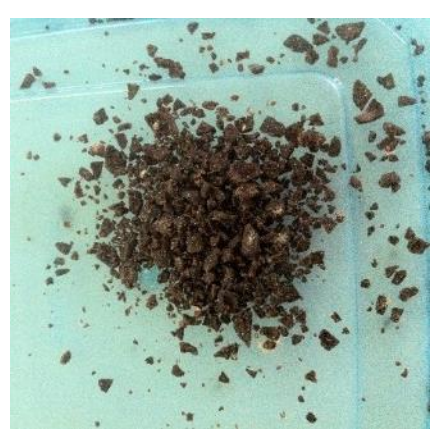

Gambar 6. Protein Kulit Udang

Kadar protein merupakan parameter untuk menentukan tingkat kemurnian protein. Kadar protein menentukan kandungan protein yang terdapat dalam suatu bahan [8]. Tabel 6 menunjukkan kadar protein yang diperoleh sebesar 86,24\% dan telah memenuhi standar mutu protein sebagai bahan pakan, yaitu sekurangkurangnya adalah $40 \%$. Kadar $\mathrm{pH}$ merupakan 
parameter yang menunjukkan tingkat keasaman dan kebasaan suatu bahan. Oleh karena itu hasil protein yang diperoleh harus dipastikan memiliki pH netral mengingat penggunaannya di bidang pakan.

\section{Kesimpulan}

Kondisi optimum untuk proses pengambilan protein selama proses isolasi kitin dari kulit udang adalah konsentrasi $\mathrm{KOH}\left(\mathrm{X}_{1}\right)$ 2,98 $\mathrm{M}$, suhu reaksi $\left(\mathrm{X}_{2}\right) 45,76{ }^{\circ} \mathrm{C}$ dan waktu reaksi $\left(\mathrm{X}_{3}\right)$ selama 90,51 menit dengan yield tertinggi sebesar $64,5826 \%$. Protein yang telah diperoleh memenuhi Standar Nasional Indonesia (SNI) mutu protein sebagai pakan ternak dengan kadar protein sebesar $86,24 \%$.

\section{Daftar Pustaka}

[1] A.E.El-Beltagy and S. M. El-Sayed, Functional and Nutritional Characteristic of Protein Recovered During Isolation of Chitin from Shrimp Waste, International Journal of Food and Bioproducts Processing, 90, (2012) 635-638.

[2] Agung Marssada Biorata, Optimasi Produk Selulase dari Bacillus sp. BPPT CC RK 2 Menggunakan Metode Respon Permukaan dengan Rasio C/N dan Waktu Fermentasi, Skripsi, Fakultas Teknik, Universitas Indonesia, Depok, 2012.

[3] Azhar, Minda, Jon Efendi, Erda Syofyeni, Rafni Marfa Lesi dan Sri Novalina, Pengaruh Konsentrasi $\mathrm{NaOH}$ dan $\mathrm{KOH}$ terhadap Derajat Deasetilasi Kitin dari Limbah Kulit Udang, Jurnal Eksakta, 1, (2010).

[4] D. Ramyadevi, Subathira A. and Saravanan S., Potential Recovery from Shrimp Waste in Aqueous Two Phase System, Research Journal of Chemical Sciences, 2, (2012) 4752.

[5] Ichda Chayati dan Andian Ari A., Bahan Ajar Kimia Pangan, Universitas Negeri Yogyakarta, Yogyakarta, 2008.

[6] Kementerian Kelautan dan Perikanan Republik Indonesia, Laporan Kinerja Kementerian Kelautan dan Perikanan Tahun 2014, Jakarta, 2014, www.kkp.go.id, diakses pada 30 Maret 2016.

[7] Lucky Indrati Utami, Isolasi Protein dari Ampas Kecap dengan Cara Ekstraksi Soda (Insulation of Protein from Dregs Taste by Extraction Soda), Skripsi, UPN Veteran, Jawa Timur, 2009.

[8] Meirinda Hermiastuti, Analisis Kadar Protein dan Identifikasi Asam Amino pada Ikan Patin (Pangasius djambal), Skripsi, Universitas Jember, Jember, 2013.
[9] Mini Bajaj, Josef Winter and Claudia Gallert, Effect of Deproteination and Deacetylation Condisions on Viscosity of Chitin and Chitosan Extracted from Crangon crangon Shrimp Waste, Biocheimcal Engineering Journal, 56, (2011) $51-62$.

[10] M. S. Benhabiles, N. Abdi, N. Drouiche, H. Lounici, A. Pauss, M. F. A. Goosen and N. Mameri, Protein Recovery by Ultrafiltration During Isolation of Chitosan from Shrimp Shells Parapenaeus longirostris, International Journal of Food Hydrocolloids, 32, (2012) 28-34.

[11] Nurjana Ahmad, Kajian Terhadap Kadar Air Tepung Jagung dan Tepung Karaginan sebagai Bahan Baku Puding Jagung, Unspecified Thesis, Universitas Negeri Gorontalo, Gorontalo, 2014.

[12] Pusat Kajian Sumberdaya Pesisir dan Lautan Institut Pertanian Bogor, Menuju Produksi Udang Nomor Satu, Bogor, 2015, www.pkspl.ipb.ac.id, diakses pada 30 Maret 2016.

[13] Rokshana Naznin, Extraction of Chitin and Chitosan from Shrimp (Metapenaeus Monoceros) Shell by Chemical Method, Pakistan Journal of Biological Sciences, 8, (2005) 1051-1054.

[14] Sri M. F. Mulyaningsih, Rudi Firyanto, Ahmad Shobib dan Nofrin Susilowati, Prosiding SENATEK, ISBN : 978 - $602-$ $1435-0-2$, Universitas Muhammadiyah, Purwokerto, 2015.

[15] Sun-Ok Fernandez B. S. Kim, Physicochemical and Functional Properties of Crawfish Chitosan as Affected by Different Processing Protocols, Thesis, Seoul National University, Seoul, 2004.

[16] Yudhi Soetrisno Garno,Pengembangan Budidaya Udang dan Potensi Pencemerannya pada Perairan Pesisir, Jurnal Lingkungan P3TL-BPPT5, 3, (2004) 187192.

[17] Z. Randriamahatody., K. S. B. Sylla, H. T. M. Nguyen, C. Donnay-Moreno, L. Razanamparany, N. Bourgougnon and J. P. Berge, Proteolysis of Shrimp By-Products (Paneus monodon) from Madagascar, CyTA-Journal of Food, 11, (2011) 220-228. 